\title{
KEUNGGULAN KOMPETITIF DAN PENAWARAN EKSPOR TUNA INDONESIA DI PASAR INTERNASIONAL MARKET SHARE CONSTANT ANALYSIS
}

\author{
Suwarno $^{1}$, Rina Oktaviani ${ }^{2}$, Hermanto Siregar $^{2}$, Endah Murniningtyas $^{3}$ \\ ${ }^{1}$ Mahasiswa Pascasarjana \\ Institut Pertanian Bogor \\ ${ }^{2}$ Departemen Ilmu Ekonomi \\ Institut Pertanian Bogor \\ ${ }^{3}$ Institut Pertanian Bogor
}

Artikel diterima Juni 2012

Artikel disetujui untuk dipublikasikan Desember 2012

\begin{abstract}
The purposes of this study are to analyze sources of tuna export growth in international market. The analysis methode of this study is Constant Market Share Analyis (CMSA). Based on the result study, Indonesia show an increase in tuna commodity export in international market because of an increase export growth in international market. Indonesia has an increase in competitiveness for frozen tuna, for example yellowfin tuna, skypjack tuna, tuna ness, and for prepared-preserved tuna, for example skypjack tuna. The important factors affecting tuna export supply are gross national product and tuna production.

Keywords: tuna, Constant Market Share Analyis, competitiveness, export supply.
\end{abstract}

\section{ABSTRAK}

Tujuan dari penelitian ini adalah untuk menganalisis sumber pertumbuhan ekspor ikan tuna di pasar internasional. Metode analisis dari studi ini adalah Constant Market Share Analysis (CMSA). Berdasarkan hasil studi, Indonesia menunjukkan peningkatan dalam ekspor komoditas tuna di pasar internasional dikarenakan peningkatan ekspor pertumbuhan di pasar internasional. Indonesia memiliki peningkatan daya saing untuk tuna beku, misalnya yellowfin tuna, skypjack tuna, tuna ness, dan tuna yang siap diawetkan, misalnya skypjack tuna. Faktor-faktor penting yang mempengaruhi supply tuna ekspor adalah Produk Nasional Bruto dan produksi tuna.

Kata kunci: tuna, Constant Market Share Analysis, daya saing, supply ekspor.

\section{PENDAHULUAN}

\section{Latar Belakang}

\subsection{Latar Belakang}

Perdagangan internasional produk perikanan laut merupakan bisnis yang besar meskipun secara global ikan laut yang dieksploitasi mengalami penurunan. Menurut laporan Food and Agriculture Organization (FAO, 2001), hampir 40 persen produksi ikan dunia diperdagangkan secara global dan jauh lebih besar dibandingkan bahan pokok lainnya seperti gandum (20 persen) dan beras ( 5 persen). Oleh karena itu, dalam perdagangan internasional ikan dan produk perikanan dapat dikatakan merupakan komoditas perdagangan yang sangat prospektif. Dalam perkembangannya, perdagangan ikan selama periode 2002- 
2006 menunjukkan kecenderungan yang terus meningkat baik volume maupun nilainya (Satria et al. 2009). Rata-rata peningkatan nilai ekspor perikanan dunia selama periode 2002-2006 telah mencapai sekitar 10 persen. Pada tahun 2006, nilai ekspor perikanan dunia telah mencapai nilai sebesar USD 86,4 miliar. Nilai ekspor yang tinggi tersebut menggambarkan bahwa produk perikanan merupakan komoditas yang sangat penting di pasar dunia.

Selama periode 2000-2009, pertumbuhan ekspor perikanan di
Indonesia cenderung lebih cepat dari pertumbuhan produksi perikanan nasional. Pada Tabel 1 dapat dilihat bahwa produksi perikanan nasional Indonesia tumbuh sekitar 2,7 persen per tahun, sementara itu pertumbuhan ekspornya tumbuh lebih besar, yaitu sekitar 3,2 persen per tahun. Hal ini dapat dikatakan bahwa kegiatan ekspor hasil perikanan selama 10 tahun terakhir ini mempunyai prospek yang cukup bagus dan secara realtif produk perikanan yang dihasilkan banyak diekspor daripada dikonsumsi dalam negeri.

Tabel 1. Perkembangan Produksi dan Ekspor Perikanan Indonesia Menurut Komoditas Utama 2000-2009

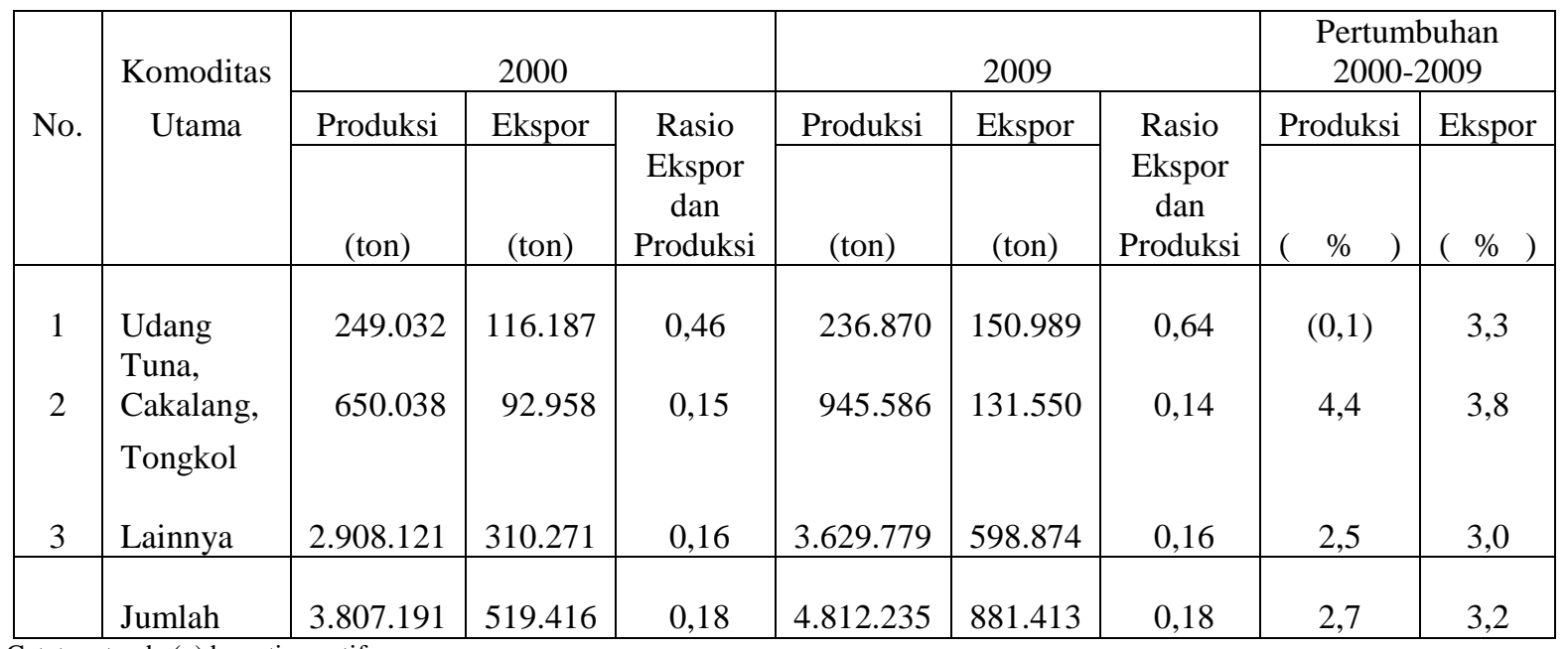

Catatan: tanda ( ) berarti negatif
Sumber: - Statistik Perikanan Tangkap 2005, Departemen Kelautan dan Perikanan

- Kelautan dan Perikanan Dalam Angka 2011, Kementerian Kelautan dan Perikanan

Selanjutnya, pertumbuhan produksi dan ekspor tuna Indonesia cenderung lebih tinggi dari komoditas perikanan udang dan komoditas ikan lainnya. Selama periode 1999-2009, Tabel 1 menunjukkan bahwa pertumbuhan produksi komoditas perikanan tuna adalah sebesar 4,4 persen per tahun dan pertumbuhan ekspornya adalah sebesar 3,8 per tahun. Sementara itu, komposisi produksi komoditas perikanan tuna yang diekspor relatif stabil yaitu berkisar antara 14-15 persen. Hal ini memberikan indikasi bahwa produksi hasil perikanan tuna Indonesia relatif cenderung banyak dikonsumsi di dalam negeri daripada diekspor. Oleh karena itu, baik dilihat dari aspek ketersediaan sumber daya (produksi) dan pertumbuhan ekspor perikanan tuna dibandingkan dengan komoditas lainnya, ekspor komoditas perikanan tuna nampaknya masih mempunyai prospek untuk bisa dikembangkan dan ditingkatkan.

Tabel 2 memberikan gambaran bahwa telah terjadi komposisi pergeseran sumbangan ekspor hasil perikanan Indonesia di pasar internasional menurut jenis komoditas ikan. Komoditas ikan lainnya menunjukkan sumbangan yang semakin besar, baik dari jumlah volume maupun nilainya, yaitu pada tahun 2002 adalah masing-masing sebesar 61,5 persen dan 33,0 persen dan pada tahun 2009 meningkat menjadi masing-masing sebesar 
67,9 persen dan 39,0 persen. Sementara itu, komoditas perikanan tuna mempunyai sumbangan ekspor hasil perikanan yang relatif stabil dan masih unggul apabila dibandingkan dengan komoditas udang. Meskipun sumbangan volume ekspor cenderung menurun, yaitu pada tahun 2002 sebesar 16,4 persen dan pada tahun 2009 menjadi 14,9 persen, namun sumbangan dari nilai ekspor tampak menunjukan peningkatan yaitu dari sebesar 13,5 persen pada tahun 2002 menjadi sekitar 13,9 persen pada tahun 2009. Hal ini menunjukkan bahwa ekspor tuna di pasar internasional cenderung mempunyai tingkat daya saing yang relatif lebih tinggi dibandingkan dengan ekspor komoditas ikan lainnya.

Tabel 2. Perkembangan Ekspor dan Harga Ikan Indonesia Menurut Komoditas di Pasar Internasional 2002-2009

\begin{tabular}{|c|c|c|c|c|c|c|c|c|c|c|c|}
\hline \multirow{3}{*}{ No. } & \multirow{3}{*}{$\begin{array}{c}\text { Komoditas } \\
\text { Utama }\end{array}$} & \multicolumn{4}{|c|}{2002} & \multicolumn{4}{|c|}{2009} & \multicolumn{2}{|c|}{$\begin{array}{c}\text { Rata-rata Harga } \\
\text { Tuna } \\
\end{array}$} \\
\hline & & Volume & Share & Nilai & Share & Volume & Share & Nilai & Share & 2002 & 2009 \\
\hline & & (ton) & $(\%)$ & (US\$ 1000) & $(\%)$ & (ton) & $(\%)$ & (US\$ 1000) & $(\%)$ & US\$ & US\$ \\
\hline 1 & $\begin{array}{l}\text { Udang } \\
\text { Tuna, }\end{array}$ & 124.763 & 22,1 & 839.722 & 53,5 & 150.989 & 17,1 & 1.029 .935 & 47,1 & $6.730,5$ & $6.821,3$ \\
\hline 2 & Cakalang, & 92.797 & 16,4 & 212.426 & 13,5 & 131.550 & 14,9 & 304.348 & 13,9 & $2.289,1$ & $2.313,6$ \\
\hline 3 & Lainnya & 348.180 & 61,5 & 518.205 & 33,0 & 598.874 & 67,9 & 854.470 & 39,0 & $1.488,3$ & $1.426,8$ \\
\hline & Jumlah & 565.740 & 100,0 & 1.570 .353 & 100,0 & 881.413 & 100,0 & 2.188 .753 & 100,0 & $2.775,8$ & $2.483,2$ \\
\hline
\end{tabular}

Sumber: Kelautan dan Perikanan Dalam Angka 2011, Kementerian Kelautan dan Perikanan

Peningkatan daya saing ikan tuna di atas dapat dicerminkan dari adanya peningkatan harga. Selama 2002-2009, rata-rata harga komoditas udang dan perikanan tuna meningkat masing-masing sebesar 0,2 persen, yaitu dari harga sebesar $6.730,5$ US\$ dan 2.289,1 US\$ pada tahun 2002 menjadi sekitar 6.821,3 US\$ dan 2.313,6 US\$ pada tahun 2009. Sebaliknya harga komoditas ikan lainnya turun sekitar 0,6 persen. Penurunan volume ekspor komoditas tuna yang dibarengi dengan peningkatan nilai dan harga ekspor komoditas tuna, hal ini menunjukkan bahwa ekspor komoditas perikanan tuna di pasar Internasional cenderung mempuyai tingkat kompetitif yang semakin tinggi yang diduga sebagai adanya peningkatan kualitas dan keamanan mutu produkproduk ekspor tuna tersebut.

Kegiatan ekspor perikanan sangat terkait dengan adanya permintaan akan kebutuhan pangan dunia, yang secara tidak langsung akan mempengaruhi terjadinya peningkatan transaksi perdagangan perikanan Indonesia di pasar internasional.
Menurut Lambaga (2009) pasar perikanan dunia yang potensial bagi Indonesia dapat dikelompokkan ke dalam 3 (tiga) wilayah pasar potensial yaitu negara-negara Asia, wilayah Amerika, dan wilayah Eropa.

Selama periode tahun 2007-2010, secara umum sumbangan volume komoditas ikan tuna di pasar internasional relatif mengalami penurunan, meskipun nilai ekspornya menunjukan peningkatan. Sebagaimana telah disebutkan di atas, harga merupakan cerminan dari kualitas produk ikan tuna agar dapat berkompetisi dalam rangka peningkatan nilai ekspor tuna Indonesia di pasar internasional. Selama 4 (empat) tahun terakhir ini, nampaknya produk perikanan tuna Indonesia mampu bersaing di Jepang dan di kelompok negara lainnya. Harga ikan tuna Indonesia yang tertinggi terjadi di pasar produktif-Jepang dan yang terendah adalah di kelompok negara lainnya.

Negara Jepang dan Amerika serikat merupakan negara pengimpor utama tuna dari Indonesia dengan berbagai jenis tuna, seperti albacore, yellowfin, big-eye, 
bulefin, dan shourten bluefin (Satria et.al 2009). Jepang merupakan potensi pasar tuna yang sangat baik mengingat tingkat konsumsi ikan di negara tersebut sangat tinggi. Penurunan ini diduga dipengaruhi kondisi perekonomian Jepang yang mengalami penurunan, yang memberikan dampak pada penurunan daya beli masyarakat terhadap produk-produk pangan, terutama seafood. Sementara itu, jenis tuna yang paling banyak diimpor oleh USA adalah jenis tuna yellowfin yang merupakan salah satu tuna yang memiliki nilai ekonomi tinggi. Krisis ekonomi yang sedang dialami oleh USA secara signifikan tidak berpengaruh pada permintaan agregat akan impor ikan tuna dari Indonesia. Dampak yang terjadi hanyalah terjadinya pergeseran preferensi konsumen dalam mengkonsumsi produk-produk perikanan.

Maisng-masing negara seperti Jepang, Amerika Serikat, Uni Eropa mempunyai selera yang berbeda terhadap kebutuhan akan impor ikan tuna. Di Jepang, komoditas perikanan tuna sangat digemari sebagai bahan baku untuk membuat sashimi sebab ikan tuna merupakan bahan baku sashimi yang tidak menimbulkan bau amis. Eropa dan Amerika Serikat lebih menyukai mengimpor ikan tuna dari Indonesia dalam bentuk ikan tuna beku dan produk ikan tuna kaleng untuk bahan baku steak (Nazzaruddin 1993). Sebaliknya, penyebab dari penurunan ekspor ikan tuna ke berbagai negara tersebut di atas, adalah terkait dengan banyak diberlakukannya beberapa hambatan tarif dan non tarif, yang dalam hal itu membuat ekspor ikan tuna Indonesia menjadi semakin lemah. Oleh karena itu, komoditas ikan tuna patut dikelola dengan baik agar dalam kancah perdagangan perikanan dunia masih terus mampu bertahan dalam menghadapi persaingan di pasar internasional.

Untuk pasar ekspor tuna beku, Indonesia masih termasuk dalam kelompok 10 pengekspor terbesar. Namun, posisinya berada pada urutan ke 6 sampai
9, dan lebih rendah dari pangsa pasar Philipina. Bahkan pada tahun 2004, ekspor tuna sirip kuning beku Indonesia lebih rendah dari Maldives, yang akhirnya menemaptkan posisi Indonesia berada pada urutan ke 11. Negara eksportir utama tuna sirip kuning beku dunia adalah Perancis, Korea, Meksiko, dan Columbia. Selama 3 tahun terakhir, Panama mengalami perkembangan yang sangat drastis dalam mengekspor tuna sirip kuning beku sehingga mampu memberikan share (sumbangan) yang paling besar pada ekspor tuna sirip kuning beku di pasar dunia. Fenomena ini menjelaskan bahwa pada komoditi olahan atau sedikitnya pengawetan, Indonesia masih perlu pembenahan. Walaupun kenyataan secara bisnis, harga tuna sirip kuning segar masih lebih tinggi apabila dibandingkan dengan produk ikan tuna non segar.

Selain ekspor tuna beku dan segar, ekspor tuna dalam bentuk olahan (kaleng) masih mempunyai peluang yang besar untuk dikembangkan. Berdasarkan hasil rancangan Roadmap Pengembagan Industri Pengolahan Hasil Laut Departemen Perindustrian (2009) disebutkan bahwa permintaan pasar dunia terhadap produk industri pengalengan ikan Indonesia masih sangat besar, sementara itu kontribusi produk industri pengalengan ikan nasional masih sangat kecil (4 persen). Pemain utama regional dan dunia di industri pengolahan ikan, khusunya tuna dan sardines adalah Thailand. Negara Thailand merupakan negara eksportir utama tuna kaleng. Nampaknya, negara Philipina juga mempunyai prospek yang cukup bagus dalam pengembangan industri tuna kaleng. Sementara itu, Amerika Serikat merupakan negara importer tuna kaleng dan di sisi lain Uni Eropa nampak terus menunjukkan peningkatan konsumsi akan tuna kaleng. Dalam beberapa tahun belakangan ini, ekspor ikan olahan (kaleng) dari Indonesia didominasi oleh ikan tuna kaleng. Pasar ekspor tuna kaleng Indonesia adalah di 
kawasan Asia, Asia pasifik, Eropa, Amerika, dan Afrika.

Satu persoalan yang cukup penting untuk dicermati dalam rangka meningkatkan ekspor tuna di pasar internasional adalah munculnya negara pesaing dalam kegiatan ekspor ikan tuna saat ini. Beberapa negara di Asean sebagai pesaing ekspor tuna di pasar internasional adalah Thailand dan Philipina. Oleh karea itu, upaya peningkatan mutu produk ikan tuna akan menjadi faktor penting dalam melakukan perdagangan tuna di pasar internasional. Oleh karena itu, efisiensi merupakan faktor kunci dalam memenangkan kompetisi (Tajerin dan Mursidin 2006) dalam perdagangan ikan tuna di pasar internasional.

Dengan demikian, berdasarkan gambaran di atas dan latar belakang penelitian ini maka rumusan permasalahan dalam penelitian ini adalah:

1. Apakah selama ini tingkat daya saing ekspor tuna Indonesia di pasar internasional telah didukung oleh faktor-faktor internal yang cukup memadai;

2. apakah kondisi faktor-faktor internal baik yang terkait dengan ketersediaan sumber daya produksi, ketersediaan perusahaan pengolah ikan tuna, aspek teknologi armada penangkapan ikan, dan aspek pendapatan nasional (pengeluaran dan produksi) mempunyai pengaruh terhadap kinerja penawaran ekspor tuna Indonesia selama ini;

\subsection{Tujuan Penelitian}

Berdasarkan pembahasan dalam latar belakang dan perumusan permasalahan dalam penelitian ini, maka tujuan penelitian ini adalah :

1) Menganalisis daya saing dan sumbersumber perubahan ekspor ikan tuna di pasar internasional;

2) Mengkaji faktor-faktor yang mempengaruhi penawaran ekspor tuna Indonesia di pasar internasional;

\subsection{Kegunaan Penelitian}

Berkenaan dengan perumusan masalah serta tujuan penelitian maka diharapkan penelitian ini bermanfaat bagi: :

1) Sebagai rekomendasi bagi para pengambil keputusan dan para pelaku ekonomi untuk dapat memperjuangkan kepentingan Indonesia dalam meningkatkan pangsa pasar ekspor perikanan tuna Indonesia di pasar internasional dalam rangka mempertahankan pemenuhan ekspor tuna sesuai dengan persyaratan yang telah ditetapkan oleh masing-masing negara pengimpor ikan tuna dari Indonesia;

2) Sebagai rekomendasi untuk membenahi kemampuan dan kelemahan terhadap strategi pengembangan dan peningkatan daya saing kinerja ekspor tuna selama ini.

3) Sebagai bahan rekomendasi pengambilan kebijakan-kebijakan pengembangan dan peningkatan penawaran ekspor dan daya saing tuna di pasar internasional.

\section{METODOLOGI PENELITIAN}

\subsection{Kerangka Pemikiran Analisa Daya Saing dan Penawaran Ekspor \\ Indonesia merupakan salah satu} negara penghasil dan sekaligus pengekspor ikan tuna. Sebagai negara pengekspor, Indonesia mempunyai beberapa pesaing utama dalam perdagangan ikan tuna di pasar internasional, seperti Thailand, China, Mauritius, Perancis, Philipina, Singapore, Jepang, dan Australia. Pasar utama ikan tuna Indonesia saat ini adalah Jepang, Uni Eropa, dan Amerika Serikat. Selain di tiga wilayah tersebut, Indonesia mulai melakukan diversifikasi pasar ekspor tuna ke beberapa negara Timur Tengah. Meskipun prospek pasar ikan tuna Indonesia tampak masih terbuka lebar, hal itu tidak serta merta produk perikanan tuna dari Indonesia dengan mudah bisa memasuki pasar tuna di pasar internasional tersebut. 


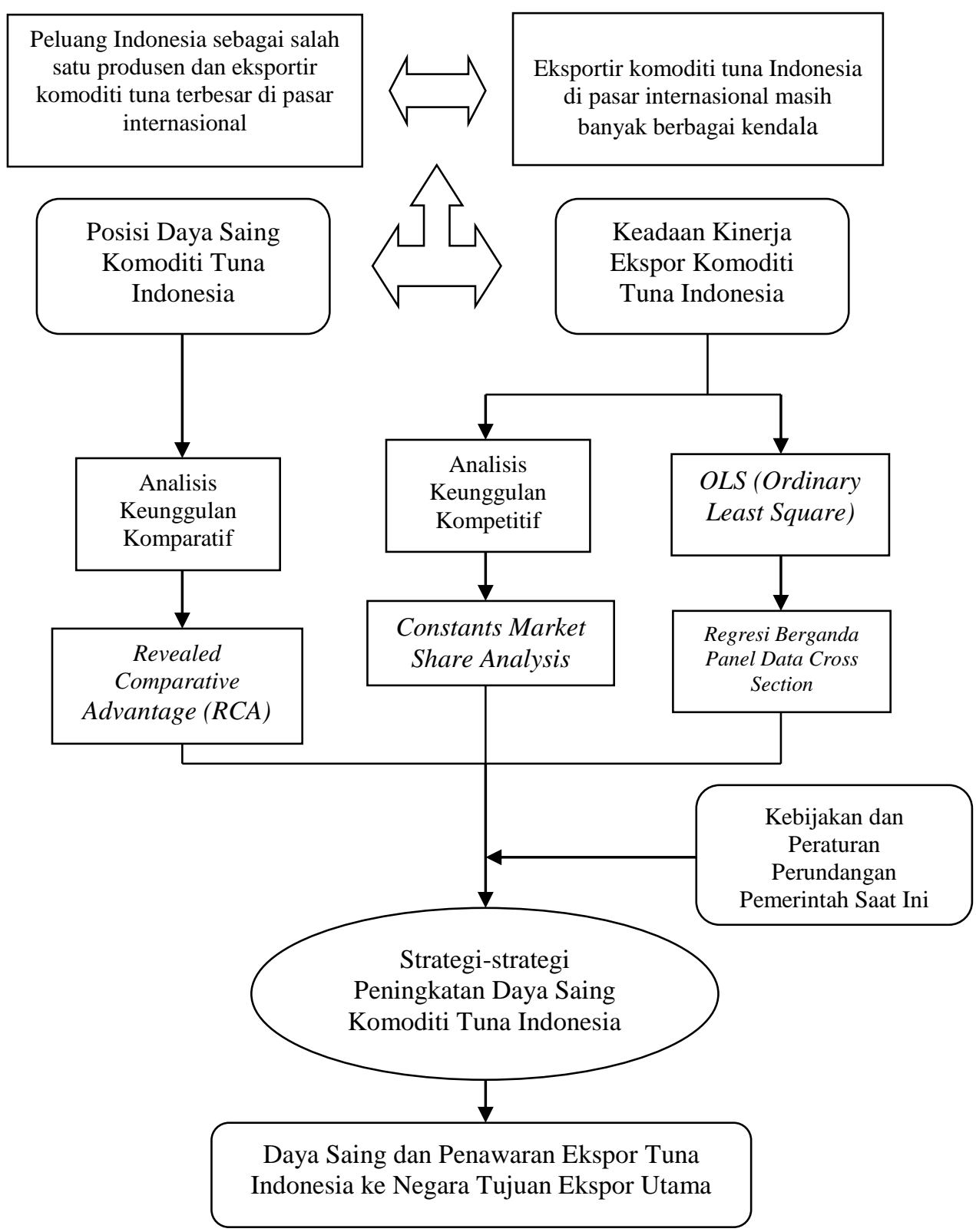

Gambar 1. Kerangka Pemikiran Analisis Daya Saing dan Penawaran Ekspor Tuna

Berbicara bagaimana tingkat daya saing dan ekspor produk perikanan tuna Indonesia, penelitian ini mencoba mengkaji apakah dalam upaya meningkatkan daya saing dan ekspor tuna tidak dihadapkan adanya berbagai permasalahan? Masalah internal maupun eksternal nampaknya banyak dijumpai dalam upaya meningkatkan daya saing dan kinerja ekspor ikan tuna Indonesia. Untuk merespon segala upaya bagaimana meningkatkan daya saing dan kinerja ekspor tuna Indonesia, penelitian ini setidaknya akan menampilkan potret daya saing dan mencari tahu terhadap faktor- faktor apa sajakah yang mempenagruhi peningkatan daya saing dan kinerja ekspor tuna Indonesia.

Keunggulan daya saing sangat diperlukan dalam upaya mempertahankan dan bahkan meningkatkan pangsa pasar dan peranannya ekspor tuna Indonesia dalam perdagangan internasional. Oleh karena itu, berdasarkan judul penelitian yang telah kami ajukan di atas, tujuan dari penelitian akan diarahkan untuk menganalisis posisi daya saing melalui keunggulan kompetitif (menggunakan CMSA/ Constant Market Share Analysis) dari komoditas tuna serta menganalisis 
faktor-faktor yang mempengaruhi ekspor tuna di Indonesia dan merumuskan strategi untuk mengembangkan dan meningkatkan daya saing komoditi ikan tuna Indonesia di pasar internasional. Analisis keunggulan komaparatif dan keunggulan kompetitif dalam penelitian ini lebih menekankan pada aspek analisis kualitatif.

Selanjutnya, analisis kuantitatif yang dipergunakan dalam penelitian ini adalah model ekonometrik dengan metode OLS (Ordinary Least Square). Melalui metode OLS dibarengi dengan teknik analisa time series regresi berganda panel data cross section, model ekonometrik ini akan digunakan untuk menganalisis faktorfaktor yang mempengaruhi daya saing komoditas tuna Indonesia di pasar internasional. Dengan menterpadukan berbagai metode analisis dalam penelitian ini, maka berikut ini dapat disusun konseptual kerangka pemikiran penelitian sebagaimana Gambar 1 di atas.

\subsection{Hipotesa Penelitian}

Berdasarkan tujuan penelitian yang telah dutetapkan, dapat diperkirakan beberapa hipotesis sebagai berikut:

1. Daya saing merupakan faktor utama penentu ekspor tuna;

2. Terkait dengan penawaran ekspor dapat perlu dibuktikan bahwa jumlah armada kapal penangkapan ikan dengan ukuran lebih dari 30 Gross Tonage, PDB Indonesia, unit pengolahan ikan, dan produksi ikan tuna baik dari sisi bentuk dan jenis komoditas ikan tuna berdampak positip terhadap peningkatan ekspor komoditas perikanan tuna.

\subsection{Alat Analisis}

Analisis Constant Market Share (CMSA) atau model pangsa pasar konstan merupakan model analisis daya saing yang digunakan untuk mengetahui keunggulan kompetitif atau daya saing ekspor di pasar dunia dari suatu negara produsen relatif terhadap negara pesaing. CMSA berguna untuk mengidentifikasi sumber-sumber perubahan ekspor. Karakteristik asumsi dan logika yang mendasari metode perhitungan ini adalah bahwa pangsa ekspor suatu negara dari suatu pasar tertentu tidak akan berubah dari waktu ke waktu. Untuk itu, selisih antara peningkatan (penurunan) impor atau ekspor aktual suatu negara pada suatu pasar tertentu di satu sisi, serta pangsa impor atau ekspor negara yang tidak berubah di sisi lainnya, dapat disebabkan oleh adanya tiga faktor sebagai berikut: (1) efek dari peningkatan (penurunan) impor (ekspor) secara umum pada suatu pasar, (2) perubahan komposisi produk, dan (3) perubahan daya saing.

Selain itu, daam penelitian ini juga akan dipergunakan analisis regresi berganda degan menggunakan pendekatan data panel. Ekonometrika mengenal tiga bentuk data antara lain time series data, cross section data serta pooled data. Dalam sebuah penelitian, kadang kala terdapat masalah mengenai ketersediaan data (data availability) untuk mewakili variabel yang digunakan dalam penelitian. Misalnya, data yang tersedia dalam bentuk series yang terlalu pendek sehingga proses pengolahan data time series tidak dapat dilakukan berkaitan dengan persyaratan jumlah data yang minim, atau data yang ada dalam bentuk unit cross section yang terbatas, sehingga proses pengolahan data cross section untuk mendapatkan informasi perilaku dari model yang diteliti sulit untuk dilakukan. Dalam teori ekonometrika, kedua kondisi tersebut dapat diatasi dengan menggunakan data panel (pooled data) agar dapat diperoleh hasil estimasi yang lebih baik (efisien) dengan terjadinya peningkatan jumlah observasi yang berimplikasi terhadap peningkatan derajat kebebasan (degree of freedom). Selain itu, penggunaan data panel ini memungkinkan untuk dapat menangkap karakteristik antar individu dan antar waktu yang berbeda-beda.

Model penawaran ekspor tuna dapat dituliskan sebagai berikut: 
Persamaan model tersebut dapat dituliskan sebagai berikut:

$\mathrm{QXN}=\beta_{0}+\beta_{1}$ KAPAL $+\beta_{2}$ PRODN + $\beta_{3} \mathrm{PDB}+\beta_{4}$ UPITOT

$\mathrm{QXBS}=\beta_{5}+\beta_{6} \mathrm{KAPAL}+\beta_{7} \mathrm{PRODBS}+$ $\beta_{8} \mathrm{PDB}+\beta_{9}$ UPITOT

QXAY $=\beta_{10}+\beta_{11}$ KAPAL $+\beta_{12}$ PRODAY $+\beta_{13} \mathrm{PDB}+\beta_{14}$ UPITOT

dimana:

$\beta_{1}, \beta_{2}, \beta_{3}, \beta_{4}, \beta_{6}, \beta_{7}, \beta_{8}, \beta_{9}, \beta_{11}, \beta_{12}, \beta_{13}, \beta_{14}>$ 0

Untuk menjelaskan beberapa variabel tersebut di atas, berikut ini kami sampiakan sumber daya dan penjelasan operasional yang terkait dengan data-data yang dipergunaan dalam penelitian ini.

Bebarapa hal yang perlu diketahui dalam penelitian ini adalah:

1) Daya saing: kemampuan suatu negara/ perusahaan mempertahankan pangsa pasar. Dikatakan memiliki daya saing atau keunggulan kompetitif apabila keberlanjutan pangsa suatu negara/perusahaan lebih besar dibandingkan pesaingnya. Sebuah industri kehilangan daya saing apabila terjadi penurunan pangsa pasar. Perubahan pangsa ekspor tidak sepenuhnya dapat menggambarkan daya saing, meskipun pangsa pasar itu sendiri paling tidak merupakan ukuran yang menggambarkan daya saing suatu negara/ perusahaan di pasar internasional.

2) Penawaran Ekspor: mengacu pada jumlah barang (tuna) yang diperdagangkan dari suatu negara ke negara tujuan mitra dagang. Data penawaran ekspor merupakan data sekunder yang bersumber dari UNComtrade. Data yang dipergunakan dalam penelitian ini mencakup kurun waktu 1999-2009. Dalam persamaan model ekonometrik, penawaran ekspor ini berfungsi sebagai dependent variable yang dinyatakan dalam jumlah ton ikan tuna. Data penawaran ekspor ini dibagi ke dalam tiga jenis data: (a) data penawaran ekspor tuna nasional $(\mathrm{OXN})$, (b) data penawaran ekspor tuna albacore dan yellowfin (OXAY), dan (c) data penawaran ekspor tuna big-eye dan skypjack (OXBS).

3) Kapal: merupakan jumlah armada penangkapan ikan tuna di atas 30 gross tonage. Variabel kapal ini digunakan sebagai peran teknologi dalam model. Data jumlah armada penangkapan ikan tuna di atas 30 gross tonage merupakan data sekunder yang bersumber dari Kementerian Kelautan dan Perikanan. Data yang dipergunakan dalam penelitian ini adalah data periode waktu 1999-2009. Jumlah armada penangkapan ikan dengan ukuran lebih dari 30 GT (KAPAL) ini dalam model persamaan ekonometrika berfungsi sebagai independent variable. Dalam hipotesanya, armada penangkapan ikan dengan ukuran lebih dari 30 GT (KAPAL) mempunyi pengaruh yang positif terhadap penawaran eskpor, baik pada penawaran ekspor tuna nasional (OXN), penawaran ekspor tuna albacore dan yellowfin (OXAY), dan penawaran ekspor tuna big-eye dan skypjack (OXBS).

4) Produk Domestik Bruto (PDB) Indonesia: dalam perhitungan pendapatan nasional dikenal tiga macam pendekatan yaitu: pendekatan sisi pengeluaran (konsumsi rumah tangga, pengeluaran swasta, pengeluaran pemerintah, pengeluaran luar negeri-ekspor impor), pendekatan sisi produksi, dan pendekatan sisi nilai tambah. Dalam penelitian ini dimungkinkan menggunakan pendekatan pengeluaran dan pendekatan produksi. PDB ini menggambarkan kemampuan Indonesia dalam meningkatkan produksi untuk tujuan ekspor ke pasar inetrnasional dan pasar internasional diasumsikan masih cukup berpotensi untuk menerimanya (Santoso 2002). 
5) Data PDB Indonesia merupakan data sekunder yang bersumber dari Badan Pusat Statistik atau Bank Indonesia. Data yang dipergunakan dalam penelitian ini adalah data periode waktu 1999-2009. PDB Indonesia ini dalam model persamaan ekonometrika berfungsi sebagai independent variable. Dalam hipotesanya, PDB mempunyi pengaruh yang positif terhadap penawaran eskpor, baik pada penawaran ekspor tuna nasional $(\mathrm{OXN})$, penawaran ekspor tuna albacore dan yellowfin (OXAY), dan penawaran ekspor tuna big-eye dan skypjack (OXBS).

6) Unit Pengolahan Ikan: merupakan perusahaan eksportir yang khusus melakukan kegiatan ekspor tuna dari Indonesia. Aspek kelembagaan dan kapasitas industri dapat digambarkan melalui variabel ini. Data unit pengolah ikan (UPITOT) merupakan data sekunder yang bersumber dari Kementerian Kelautan dan Perikanan. Data yang dipergunakan dalam penelitian ini adalah data periode waktu 1999-2009. Unit pengolahan ikan (UPITOT) ini dalam model persamaan ekonometrika berfungsi sebagai independent variable. Dalam hipotesanya, unit pengolahan ikan (UPITOT) mempunyi pengaruh yang positif terhadap penawaran eskpor, baik pada penawaran ekspor tuna nasional (OXN), penawaran ekspor tuna albacore dan yellowfin (OXAY), dan penawaran ekspor tuna big-eye dan skypjack (OXBS).

\section{HASIL PEMBAHASAN}

\subsection{Model Analisa Statis Keunggulan Kompetitif: Analisis Constant Market Share (CMS) Indonesia}

Selama periode 2000-2009, komponen-komponen yang menyumbang pertumbuhan ekspor dapat dianalisis dengan menggunakan model CMS. Dari hasil perhitungan analisis CMS ini sebagaimana pada Table 9 dapat disampaikan bahwa efek pertumbuhan dunia seluruhnya bertanda positip. Hal ini menunjukkan bahwa naiknya pertumbuhan ekspor di pasar tuna dunia telah menyebabkan naiknya ekspor komoditas tuna dari Indonesia. Berdasarkan efek pertumbuhan dunia tersebut, komoditas tuna yang memiliki nilai yang terbesar adalah tuna olahan $(0,18)$, tuna yellowfin segar $(0,15)$, tuna nes segar $(0,06)$, tuna yellowfin beku $(0,02)$, tuna nes beku $(0,02)$, tuna albacore beku $(0,01)$ dan tuna skipjack beku $(0,01)$.

Selanjutnya dari hasil analisis CMS ini ditemukan bahwa efek komposisi komoditas tuna Indonesia terlihat bahwa jenis tuna albacore segar, yellowfin segar, albacore beku dan yellowfin beku menunjukkan angka negatif. Sementara itu untuk jenis tunas nes segar dan beku, skipjack segar dan beku, dan skipjack olahan menunjukan nilai positif. Berdasarkan nilai efek kompoisisi komoditas tersebut dapat diduga bahwa jenis tuna albacore segar, yellowfin segar, skipjack segar, albacore beku dan yellowfin beku terdistribusi pada jenisjenis komoditas yang permintaannya relatif lambat di negara pengimpor. Sementara itu tunas nes segar, skipjack beku, tuna nes beku dan skipjack olahan terdistribusi pada jenis-jenis komoditas yang permintaannya relatif cepat di negara pengimpor. 
Tabel 3. Constant Market Share Analisys Ekspor Tuna Indoneisa 2000-2009

\begin{tabular}{lcccc}
\hline \multirow{2}{*}{ Jenis Komoditas Ekspor Tuna } & Efek & Efek & Efek & Efek \\
\cline { 2 - 5 } & Pertumbuhan & Komposisi & Distribusi & Daya \\
\cline { 2 - 5 } & Dunia & Komoditas & Pasar & Saing \\
\hline Tuna (albacore,longfin) Fresh or Chilled, whole & 0.00 & $(0.01)$ & 0.18 & $(15.34)$ \\
\hline Tuna (yellowfin,longfin) Fresh or Chilled, whole & 0.15 & $(0.35)$ & $(2.64)$ & $(308.37)$ \\
\hline $\begin{array}{l}\text { Tuna (Skipjack,stripe-belly bonito) Fresh or } \\
\text { Chilled, whole }\end{array}$ & 0.00 & $(0.02)$ & $(0.16)$ & $(18.71)$ \\
\hline Tuna nes, Fresh or Chilled, whole & 0.06 & 0,02 & $(0.00)$ & 120.55 \\
\hline Tuna (albacore,longfin) Frozen, whole & 0.01 & $(0.02)$ & 0.06 & $(10.24)$ \\
\hline Tuna (yellowfin,longfin) Frozen, whole & 0.02 & $(0.01)$ & $(0.37)$ & 31.15 \\
\hline Tuna (Skipjack,stripe-belly bonito) Frozen, whole & 0.01 & 0.01 & $(0.51)$ & 36.32 \\
\hline Tuna nes, Frozen, whole & 0.02 & 0.01 & $(2.31)$ & 41.40 \\
\hline $\begin{array}{l}\text { Tuna,Skipjack, Bonito, prepared-preserved, not } \\
\text { minced }\end{array}$ & 0.18 & 0.04 & 0.10 & 351.56 \\
\hline Catatan: ( ) angka dalam kurrung berarti negat & & & \\
\hline
\end{tabular}

Catatan: ( ) angka dalam kurung berarti negatif

Hal yang menarik untuk dicermati adalah bahwa ekspor tuna Indonesia nampaknya terdistribusi pada pasar-pasar yang impornya tumbuh relatif cepat dan pada pasar/ negara yang tumbuh begitu lambat. Beberapa komoditas yang ekspor tunanya terdistribusi pada pasar/ negara pertumbuhannya yang relatif cepat ditemukan pada beberapa komoditas, seperti tuna albacore segar, tuna albacore beku, dan tuna olahan. Untuk beberapa jenis komoditas tuna yellowfin, skipjack, dan tuna nes baik segar maupun beku cenderung terdistribusi pada pasar/ negara yang impornya tumbuh relatif lambat.

Terkait dengan ukuran perubahan ekspor sebagai hasil dari keuntungan atau keuntungan dalam pangsa ekspor, nampaknya Indonesia merupakan negara pengekspor yang mempunyai daya saing kuat untuk beberapa komoditas, tunas nes segar dan beku, tuna yellowfin beku, tuna skipjack beku, dan tuna olahan. Hal ini ditunjukkan dengan adanya indikator efek daya saing yang bernilai positip. Sebaliknya, beberapa komoditas tuna albacore segar dan beku, tuna yellowfin segar, dan tuna skipjack segar tampak mempunyai daya saing yang lemah sebagaimana ditunjukkan oleh ukuran efek daya saing yang bernilai negatif.

\subsection{Model Penawaran Ekspor Tuna}

\subsubsection{Hasil Pendugaan Model Penawaran Ekspor Tuna Nasional}

\subsubsection{Pemilihan Model}

Untuk menentukan apakah model yang digunakan dalam penelitian merupakan model common effect atau model fixed effect, hal ini dapat dilakukan dengan menggunakan Uji $F$ dan Uji Hausman. Untuk itu, perlu dilakukan adanya hipotesis sebagai berikut:

1. Ho : memilih model common effect apabila nilai probabilitas $\mathrm{F}$ statistik tidak signifikan pada $\alpha=5$ persen.

2. H1 : memilih model fixed effect apabila nilai probabilitas statistiknya signifikan pada $\alpha=5$ persen.

Nilai $F$ statistik hasil perhitungan EViews sekitar 20,7 dengan probabilitas $\mathrm{F}$ Statistik sebesar 0,0000 signifikan pada $\alpha$ $=5$ persen. Sehingga secara statistik Ho ditolak dan menerima H1. Maka model yang tepat untuk dipilih adalah model estimasi fixed effect.

Uji Hausman digunakan untuk memilih model yang terbaik antara fixed effect dan random effect. Tetapi pada saat pengujian Hausman output tidak dapat ditampilkan. Kemungkinan hal ini terjadi karena data yang sangat terbatas (data cross section hanya 3 (tiga) bentuk 
komoditas tuna - tuna segar, tuna beku, dan tuna olahan/ pengawetan selama kurun waktu 11 tahun yaitu periode tahun 19992009).

Setelah Uji Hausman tidak dilakukan disimpulkan bahwa penelitian ini untuk (penawaran ekspor tuna nasional) dipergunaan model estimasi fixed effect dalam menganalisis independent variables antara dependent variable, yaitu jumlah armada penangkapan ikan dengan ukuran lebih dari 30 GT (KAPAL), Produk Nasional Bruto Indonesia (PDB), jumlah unit pengolahan ikan (UPITOT), dan jumlah produksi ikan tuna nasional (PRODN) dengan dependent variable penawaran ekspor tuna nasional $(\mathrm{OXN})$.

\subsubsection{Pengujian Hipotesis Regresi Berganda Untuk Data Panel}

Pengujian hipotesis data panel dilakukan dengan menggunakan teknik regresi pendekatan model estimasi fixed effect. Hasil pengolahan data skunder dengan EViews pada Tabel 4 berikut ini.

Dari Tabel 4 Hasil Regresi Penawaran Ekspor Nasional dapat ditunjukkan bahwa koefisien determinasi $\left(\mathrm{R}^{2}\right)$ tersebut adalah sebesar 0,787 . Hal ini berarti bahwa indenpendent variables, seperti jumlah armada penangkapan ikan dengan ukuran lebih dari 30 GT (KAPAL), Produk Nasional Bruto Indonesia (PDB), jumlah unit pengolahan ikan (UPITOT), dan jumlah produksi ikan tuna nasional (PRODN).mampu menjelaskan variasi perkembangan penawaran ekspor tuna nasional (OXN) selama periode tahun 1999-2009 sebesar 78,7 persen, sedangkan sisanya 21,3 persen dijelaskan oleh variabel lain yang tidak dimasukkan dalam model estimasi.

Untuk menguji hipotesis pada penelitian ini digunakan statistik $\mathrm{t}$ dan statistik F. Uji statistik t digunakan untuk menguji signifikansi secara parsial, yaitu apakah masing-masing independent variables berpengaruh secara signifikan atau tidak terhadap dependent variable pada tingkat signifikansi $\alpha=5$ persen. Uji $\mathrm{F}$ digunakan untuk melihat signifikansi secara simultan yaitu secara bersama-sama apakah independent variables, seperti jumlah armada penangkapan ikan dengan ukuran lebih dari 30 GT (KAPAL), Produk Nasional Bruto Indonesia (PDB), jumlah unit pengolahan ikan (UPITOT), dan jumlah produksi ikan tuna nasional (PRODN).berpengaruh signifikan ataukah tidak terhadap penawaran ekspor tuna nasional (OXN) selama periode tahun 1999-2009 pada tingkat signifikansi $\alpha=5$ persen.

Pada uji F (Uji Simultan), dapat dilihat pada Tabel 4 di atas bahwa didapatkan $\mathrm{F}$ statistik 20,72 dengan nilai signifikansi probaabiitas $\mathrm{F}$ sebesar 0,0000 lebih kecil dari 0,05. Hal ini dapat dikatakan bahwa secara simultan terdapat pengaruh yang signifikan antara independent variables, seperti jumlah armada penangkapan ikan dengan ukuran lebih dari 30 GT (KAPAL), Produk Nasional Bruto Indonesia (PDB), jumlah unit pengolahan ikan (UPITOT), dan jumlah produksi ikan tuna nasional (PRODN).berpengaruh signifikan ataukah tidak terhadap penawaran ekspor tuna nasional (OXN) selama periode tahun 1999-2009 pada tingkat signifikansi $\alpha=5$ persen.

Pada Uji t statistik berikut ini dapat disampaikan:

\section{a. Pengaruh KAPAL Terhadap OXN}

Berdasarkan Tabel 4 di atas diperoleh signifikansi sebesar 0,157>0,05. Hal ini disimpulkan bahwa jumlah armada penangkapan ikan dengan ukuran lebih dari 30 GT (KAPAL) tidak berpengaruh secara signifikan terhadap penawaran ekspor tuna nasional $(\mathrm{OXN})$ pada $\alpha=5$ persen.

Berdasarkan hasil estimasi menunjukkan bahwa armada penangkapan ikan dengan ukuran lebih dari 30 GT (KAPAL) berpengaruh positif terhadap penawaran ekspor tuna nasional (OXN). Hal ini menunjukkan bahwa semakin banyak menambah jumlah armada penangkapan ikan dengan ukuran lebih dari 30 GT (KAPAL) akan menyebabkan 
semakin meningkatnya jumlah penawaran ekspor tuna Indonesia (OXN) di pasar internasional. Sehubungan model regresi ini berbentuk model persamaan logaritma, nilai koefisien regresi armada penangkapan ikan dengan ukuran lebih dari 30 GT (KAPAL) sebesar 0,264 menunjukkan bahwa setiap peningkatan jumlah armada penangkapan ikan dengan ukuran lebih dari 30 GT (KAPAL) sebesar 1 persen, maka jumlah penawaran ekspor tuna Indonesia $(\mathrm{OXN})$ akan meningkat sekitar 0,264 persen ton.

Tabel 4. Hasil Regresi Model Penawaran Ekspor Tuna Nasional

\begin{tabular}{|c|c|c|c|c|}
\hline Variable & Coefficient & Std. Error & t-Statistic & Prob. \\
\hline C & -8.008760 & 2.709065 & -2.956282 & 0.0065 \\
\hline LNKAPAL? & 0.264115 & 0.181163 & 1.457884 & 0.1568 \\
\hline LNPDB? & 0.794697 & 0.368207 & 2.158286 & 0.0403 \\
\hline LNUPITOT? & -0.218036 & 0.121607 & -1.792959 & 0.0846 \\
\hline LNPROD? & 0.509692 & 0.496993 & 1.025551 & 0.3146 \\
\hline \multicolumn{5}{|c|}{ Fixed Effects (Cross) } \\
\hline _BEKU--C & -0.014130 & & & \\
\hline SEGAR--C & -0.077018 & & & \\
\hline -OLAHAN--C & 0.091148 & & & \\
\hline \multicolumn{5}{|c|}{ Effects Specification } \\
\hline \multicolumn{5}{|c|}{ Cross-section fixed (dummy variables) } \\
\hline \multicolumn{5}{|c|}{ Weighted Statistics } \\
\hline R-squared & 0.827026 & \multirow{5}{*}{\multicolumn{2}{|c|}{$\begin{array}{l}\text { Mean dependent var } \\
\text { S.D. dependent var } \\
\text { Sum squared resid } \\
\text { Durbin-Watson stat }\end{array}$}} & 67.31616 \\
\hline Adjusted R-squared & 0.787109 & & & 24.98819 \\
\hline S.E. of regression & 1.083674 & & & 30.53308 \\
\hline F-statistic & 20.71867 & & & 2.009224 \\
\hline Prob(F-statistic) & 0.000000 & & & \\
\hline \multicolumn{5}{|c|}{ Unweighted Statistics } \\
\hline R-squared & 0.604912 & \multirow{2}{*}{\multicolumn{2}{|c|}{$\begin{array}{l}\text { Mean dependent var } \\
\text { Durbin-Watson stat }\end{array}$}} & 4.512988 \\
\hline Sum squared resid & 0.291657 & & & 1.499911 \\
\hline
\end{tabular}

b. Pengaruh PDB Indonesia Terhadap OXN

Berdasarkan Tabel 12 di atas diperoleh signifikansi sebesar 0,04 0,05. Hal ini disimpulkan bahwa Produk Domestik Bruto (PDB) Indonesia berpengaruh secara signifikan terhadap penawaran ekspor tuna nasional (OXN) pada $\alpha=5$ persen.

Berdasarkan hasil estimasi menunjukkan bahwa Produk Domestik Bruto (PDB) Indonesia berpengaruh positif terhadap penawaran ekspor tuna nasional (OXN). Hal ini menunjukkan bahwa semakin meningkat Produk Domestik Bruto (PDB) Indonesia akan menyebabkan semakin meningkatnya jumlah penawaran ekspor tuna Indonesia (OXN) di pasar internasional. Sehubungan model regresi ini berbentuk model persamaan logaritma, nilai Produk Domestik Bruto (PDB) Indonesia sebesar 0,795 menunjukkan bahwa setiap peningkatan Produk Domestik Bruto (PDB) Indonesia sebesar 1 persen, maka jumlah penawaran ekspor tuna Indonesia (OXN) akan meningkat sekitar 0,795 persen ton. c. Pengaruh UPITOT Terhadap OXN

Berdasarkan Tabel 4 di atas diperoleh signifikansi sebesar 0,085 >0,05. Maka disimpulkan bahwa unit pengolahan ikan (UPITOT) tidak berpengaruh secara 
signifikan terhadap penawaran ekspor tuna nasional $(\mathrm{OXN})$.

Berdasarkan hasil estimasi menunjukkan bahwa pengolahan ikan (UPITOT) berpengaruh negatif terhadap penawaran ekspor tuna nasional (OXN). Hasil hipotesis ini tidak sesuai dengan teori (studi empiris) yang ada, yang berarti pengaruh pengolahan ikan (UPITOT) terhadap penawaran ekspor tuna Indonesia (OXN) yang positif tidak terbukti. Hal ini dimungkinkan terdapatnya faktor-faktor lain unik yang sudah di luar dari kebiasaan perilaku ekonomi pada umumnya.

d. Pengaruh PRODN Terhadap OXN

Berdasarkan Tabel 4 di atas diperoleh signifikansi sebesar 0,315>0,05. Maka disimpulkan bahwa produksi ikan tuna nasional (PRODN) tidak berpengaruh secara signifikan terhadap penawaran ekspor tuna nasional $(\mathrm{OXN})$

Berdasarkan hasil estimasi menunjukkan bahwa produksi ikan tuna nasional (PRODN) berpengaruh positif terhadap penawaran ekspor tuna nasional $(\mathrm{OXN})$. Hal ini menunjukkan bahwa semakin meningkat produksi ikan tuna nasional (PRODN) akan menyebabkan semakin meningkatnya jumlah penawaran ekspor tuna Indonesia (OXN) di pasar internasional. Sehubungan model regresi ini berbentuk model persamaan logaritma, nilai koefisien produksi ikan tuna nasional (PRODN) sebesar 0,510 menunjukkan bahwa setiap peningkatan produksi ikan tuna nasional (PRODN) sebesar 1 persen, maka jumlah penawaran ekspor tuna Indonesia $(\mathrm{OXN})$ akan meningkat sekitar 0,510 persen ton.

\subsection{HasilPendugaan \\ Penawaran Ekspor Tuna (Albacore dan Yellowfin)}

\subsubsection{Pemilihan Model}

Untuk menentukan apakah model yang digunakan dalam penelitian merupakan model common effect atau model fixed effect, hal ini dapat dilakukan dengan menggunakan Uji $\mathrm{F}$ dan Uji
Hausman. Untuk itu, perlu dilakukan adanya hipotesis sebagai berikut:

1. Ho : memilih model common effect apabila nilai probabilitas $\mathrm{F}$ statistik tidak signifikan pada $\alpha=5$ persen.

2. H1 : memilih model fixed effect apabila nilai probabilitas statistiknya signifikan pada $\alpha=5$ persen.

Nilai F statistik hasil perhitungan EViews sekitar 321,5 dengan probabilitas F Statistik sebesar 0,0000 signifikan pada $\alpha=5$ persen. Sehingga secara statistik Ho ditolak dan menerima H1. Maka model yang tepat untuk dipilih adalah model estimasi fixed effect.

Uji Hausman digunakan untuk memilih model yang terbaik antara fixed effect dan random effect. Tetapi pada saat pengujian Hausman output tidak dapat ditampilkan. Kemungkinan hal ini terjadi karena data yang sangat terbatas (data cross section hanya 2 (dua) jenis komoditas tuna-tuna albacore dan tuna yellowfin selama kurun waktu 11 tahun yaitu periode tahun 1999-2009).

Setelah Uji Hausman tidak dilakukan disimpulkan bahwa penelitian ini untuk (penawaran ekspor tuna nasional) dipergunaan model estimasi fixed effect dalam menganalisis independent variables antara dependent variable, yaitu jumlah armada penangkapan ikan dengan ukuran lebih dari 30 GT (KAPAL), Produk Nasional Bruto Indonesia (PDB), jumlah unit pengolahan ikan (UPITOT), dan jumlah produksi ikan tuna albacore dan yellowfin (PRODAY) dengan dependent variable penawaran ekspor tuna albacore dan yellowfin (OXAY).

\subsubsection{Pengujian Hipotesis Regresi Berganda Untuk Data Panel \\ Pengujian hipotesis data panel} dilakukan dengan menggunakan teknik regresi pendekatan model estimasi fixed effect. Hasil pengolahan data skunder dengan EViews pada Tabel 5 berikut ini.

Dari Tabel 5 Hasil Regresi Penawaran Ekspor Tuna Albacore dan Yellowfin dapat ditunjukkan bahwa koefisien determinasi tersebut adalah 
sebesar 0,987. Hal ini berarti bahwa indenpendent variables, seperti jumlah armada penangkapan ikan dengan ukuran lebih dari 30 GT (KAPAL), Produk Nasional Bruto (PDB) Indonesia, jumlah unit pengolahan ikan (UPITOT), dan jumlah produksi ikan tuna Albacore dan Yellowfin

(PRODAY).mampu menjelaskan variasi perkembangan penawaran ekspor tuna Albacore dan Yellowfin (OXAY) selama periode tahun 1999-2009 sebesar 98,7 persen, sedangkan sisanya 1,3 persen dijelaskan oleh variabel lain yang tidak dimasukkan dalam model estimasi.

Nilai $F$ statistik hasil perhitungan Eviews sekitar 321,5 dengan probabilitas $\mathrm{F}$ Statistik sebesar 0,0000 signifikan pada $\alpha$ $=5$ persen. Sehingga secara statistik Ho ditolak dan menerima H1. Maka model yang tepat adalah model estimasi fixed effect.

Uji Hausman digunakan untuk memilih model yang terbaik antara fixed effect dan random effect. Tetapi pada saat pengujian Hausman output tidak dapat ditampilkan. Kemungkinan hal ini terjadi karena data yang sangat terbatas (data cross section hanya 2 (dua) jenis komoditas-tuna albacore dan tuna yellowfin.

Setelah Uji Hausman tidak dilakukan disimpulkan bahwa penelitian ini untuk (penawaran ekspor tuna nasional) dipergunaan model estimasi fixed effect dalam menganalisis variabel independent jumlah armada penangkapan ikan dengan ukuran lebih dari 30 GT (KAPAL), Produk Nasional Bruto (PDB) Indonesia, jumlah unit pengolahan ikan (UPITOT), dan jumlah produksi ikan tuna Albacore dan Yellowfin (PRODAY).dan dependent variable penawaran ekspor tuna Albacore dan Yellowfin (OXAY).

\subsubsection{Pengujian Hipotesis Untuk Data Panel}

Pengujian hipotesis data panel dilakukan menggunakan teknik regresi berganda dengan pendekatan model estimasi fixed effect. Hasil pengolahan data skunder dengan EViews pada Tabel 5 di bawah ini.

Tabel 5. Hasil Analisis Regresi Tuna Albacore-Yellowfin

\begin{tabular}{|c|c|c|c|c|}
\hline Variable & Coefficient & Std. Error & t-Statistic & Prob. \\
\hline $\mathrm{C}$ & 25859.99 & 7292.297 & 3.546207 & 0.0027 \\
\hline KAPAL? & 0.009640 & 0.396292 & 0.024326 & 0.9809 \\
\hline PROD? & 0.109151 & 0.010013 & 10.90113 & 0.0000 \\
\hline PDB? & $-1.61 \mathrm{E}-07$ & 5.69E-08 & -2.829264 & 0.0121 \\
\hline UPITOT? & 161.0516 & 85.76892 & 1.877738 & 0.0788 \\
\hline \multicolumn{5}{|c|}{ Fixed Effects (Cross) } \\
\hline QXAL--C & -3663.893 & & & \\
\hline \multirow[t]{2}{*}{ QXYE--C } & 3663.893 & & & \\
\hline & \multicolumn{4}{|c|}{ Effects Specification } \\
\hline \multicolumn{5}{|c|}{ Cross-section fixed (dummy variables) } \\
\hline \multicolumn{5}{|c|}{ Weighted Statistics } \\
\hline R-squared & 0.990145 & \multicolumn{2}{|c|}{ Mean dependent var } & 7.373699 \\
\hline Adjusted R-squared & 0.987065 & \multicolumn{2}{|c|}{ S.D. dependent var } & 6.425965 \\
\hline S.E. of regression & 1.108542 & \multicolumn{2}{|c|}{ Sum squared resid } & 19.66184 \\
\hline F-statistic & 321.5052 & \multicolumn{2}{|c|}{ Durbin-Watson stat } & 1.403420 \\
\hline Prob(F-statistic) & 0.000000 & & & \\
\hline \multicolumn{5}{|c|}{ Unweighted Statistics } \\
\hline R-squared & 0.971039 & Mean depeno & t var & 10397.34 \\
\hline Sum squared resid & 52846508 & Durbin-Watso & tat & 1.217632 \\
\hline
\end{tabular}


. Hasil Uji Koefisien Determinasi $\left(\mathrm{R}^{2}\right)$ digunakan untuk menguji sebearapa besar pengaruh independent variable terhadap dependent variable-nya. Berdasarkan Tabel 5, diperoleh nilai adjusted $\mathrm{R}^{2}$ sebesar 0,987 yang berarti bahwa dependent variable penawaran ekspor tuna albacore dan yellowfin (OXAY) yang dijelaskan oleh independent variables armada penangkapan ikan dengan ukuran lebih dari 30 GT (KAPAL), Produk Nasional Bruto (PDB) Indonesia, jumlah unit pengolahan ikan (UPITOT), dan jumlah produksi ikan tuna Albacore dan Yellowfin (PRODAY) sebesar 98,7 persen. Hal ini berarti bahwa pengungkapan penawaran ekspor ikan tuna Albacore dan Yellowfin (OXAY) dipengaruhi oleh independent variables armada penangkapan ikan dengan ukuran lebih dari 30 GT (KAPAL), Produk Nasional Bruto (PDB) Indonesia, jumlah unit pengolahan ikan (UPITOT), dan jumlah produksi ikan tuna Albacore dan Yellowfin (PRODAY) sebesar 98,7 persen. Sisanya sekitar 1,3 persen dipengaruhi oleh variabel lain yang tidak diteliti dalam penelitian ini.

Uji $F$ digunakan untuk melihat signifikansi secar simultan yaitu secara bersama-sama apakah variabel independents armada penangkapan ikan dengan ukuran lebih dari 30 GT (KAPAL), Produk Nasional Bruto (PDB) Indonesia, jumlah unit pengolahan ikan (UPITOT), dan jumlah produksi ikan tuna Albacore dan Yellowfin (PRODAY) berpengaruh signifikan ataukah tidak terhadap penawaran ekspor albacore-yellowfin (OXAY) pada tahun 1999-2009 pada tingkat signifikansi $\alpha=5$ persen.

Pada uji F (Uji Simultan), dapat dilihat pada Tabel $5 \mathrm{di}$ atas bahwa didapatkan $\mathrm{F}$ statistik 321,5 dengan nilai signifikansi probaabiitas $\mathrm{F}$ sebesar 0,0000 lebih kecil dari 0,05. Hal ini dapat diketahui bahwa secara simultan terdapat pengaruh signifikansi antara jumlah armada penangkapan ikan dengan ukuran lebih dari 30 GT (KAPAL), Produk
Nasional Bruto (PDB) Indonesia, jumlah unit pengolahan ikan (UPITOT), dan jumlah produksi ikan tuna Albacore dan Yellowfin (PRODAY) dengan penawaran ekspor nasional (OXAY) pada tahun 19992009.

Pada Uji t statistik berikut ini dapat disampaikan sebagai berikut:

a. Pengaruh KAPAL Terhadap OXAY

Berdasarkan tabel di atas diperoleh signifikansi sebesar 0,981>0,05. Maka disimpulkan bahwa jumlah armada penangkapan ikan dengan ukuran lebih dari 30 GT (KAPAL) tidak berpengaruh secara signifikan terhadap OXAY.

Berdasarkan hasil estimasi menunjukkan bahwa armada penangkapan ikan dengan ukuran lebih dari 30 GT (KAPAL) berpengaruh positif terhadap penawaran ekspor tuna albacore-yellowfin (OXAY). Hal ini menunjukkan bahwa semakin banyak menambah jumlah armada penangkapan ikan dengan ukuran lebih dari 30 GT (KAPAL) akan menyebabkan semakin meningkatnya jumlah penawaran ekspor tuna albacoreyellowfin (OXAY) di pasar internasional. Nilai koefisien regresi armada penangkapan ikan dengan ukuran lebih dari 30 GT (KAPAL) sebesar 0,0096 menunjukkan bahwa setiap peningkatan jumlah armada penangkapan ikan dengan ukuran lebih dari 30 GT (KAPAL) sebanyak 1 unit, maka jumlah penawaran ekspor tuna Indonesia albacore dan yellowfin (OXAY) akan meningkat sekitar 0,009 ton.

b. Pengaruh PDB Indonesia Terhadap OXAY

Berdasarkan tabel di atas diperoleh signifikansi sebesar 0,012 <0,05. Maka disimpulkan bahwa Produk Domestik Bruto (PDB) Indonesia berpengaruh secara signifikan terhadap penawaran ekspor tuna Indonesia albacore dan yellowfin (OXAY). Berdasarkan hasil estimasi menunjukkan bahwa Produk Domestik Bruto (PDB) Indonesia berpengaruh negatif terhadap penawaran ekspor 
penawaran ekspor tuna Indonesia albacore dan yellowfin (OXAY). Hal ini menunjukkan bahwa semakin meningkat Produk Domestik Bruto (PDB) Indonesia akan menyebabkan menurunnya jumlah penawaran ekspor tuna Indonesia albacore dan yellowfin (OXAY) di pasar internasional. Nilai koefisien regresi Produk Domestik Bruto (PDB) Indonesia sebesar -0,00000016 menunjukkan bahwa setiap peningkatan Produk Domestik Bruto (PDB) Indonesia sebesar 1 juta rupiah, maka jumlah penawaran ekspor tuna Indonesia albacore dan yellowfin (OXAY) akan turun sekitar 0,16 ton.

\section{c. Pengaruh UPITOT Terhadap OXAY}

Berdasarkan tabel di atas diperoleh signifikansi sebesar 0,0788>0,05. Maka disimpulkan bahwa unit pengolahan ikan (UPITOT) tidak berpengaruh secara signifikan terhadap penawaran ekspor tuna Indonesia albacore dan yellowfin (OXAY).

Berdasarkan hasil estimasi menunjukkan bahwa unit pengolahan ikan (UPITOT) berpengaruh positif terhadap penawaran ekspor tuna albacore dan yellowfin (OXAY). Hal ini menunjukkan bahwa semakin meningkat jumlah unit pengolahan ikan (UPITOT) akan menyebabkan meningkatnya jumlah penawaran ekspor tuna albacore dan yellowfin (OXAY) di pasar internasional. Nilai koefisien regresi unit pengolahan ikan (UPITOT) sebesar 161,05 menunjukkan bahwa setiap peningkatan jumlah unit pengolahan ikan (UPITOT) sebesar 1 unit, maka jumlah penawaran ekspor tuna Indonesia albacore dan yellowfin (OXAY) akan meningkat sekitar 161,05 ton.

d. Pengaruh PRODAY Terhadap OXAY

Berdasarkan tabel di atas diperoleh signifikansi sebesar $0,00<0,05$. Maka disimpulkan bahwa jumlah produksi ikan tuna Albacore dan Yellowfin (PRODAY) berpengaruh secara signifikan terhadap jumlah penawaran ekspor tuna Indonesia albacore dan yellowfin (OXAY) .
Berdasarkan hasil estimasi menunjukkan bahwa produksi ikan tuna Albacore dan Yellowfin (PRODAY) berpengaruh positif terhadap penawaran ekspor tuna albacore dan yellowfin (OXAY). Hal ini menunjukkan bahwa semakin meningkat produksi ikan tuna Albacore dan Yellowfin (PRODAY) akan menyebabkan meningkatnya jumlah penawaran ekspor tuna albacore dan yellowfin (OXAY) di pasar internasional. Nilai koefisien regresi produksi ikan tuna Albacore dan Yellowfin (PRODAY) sebesar 0,11 menunjukkan bahwa setiap peningkatan produksi ikan tuna Albacore dan Yellowfin (PRODAY) sebesar 1 ton, maka jumlah penawaran ekspor tuna Indonesia albacore dan yellowfin (OXAY) akan meningkat sekitar 0,11 ton.

\subsection{Hasil Pendugaan Model Penawaran Ekspor Tuna (Big- eye dan Skipjack) \\ 3.3.1. Pemilihan Model}

Untuk menentukan apakah model

yang digunakan dalam penelitian merupakan model common effect atau model fixed effect, hal ini dapat dilakukan dengan menggunakan Uji $F$ dan Uji Hausman. Untuk itu, perlu dilakukan adanya hipotesis sebagai berikut:

1. Ho : memilih model common effect apabila nilai probabilitas $\mathrm{F}$ statistik tidak signifikan pada $\alpha=5$ persen.

2. H1 : memilih model fixed effect apabila nilai probabilitas statistiknya signifikan pada $\alpha=5$ persen.

Nilai F statistik hasil perhitungan EViews sekitar 81,56 dengan probabilitas F Statistik sebesar 0,0000 signifikan pada $\alpha=5$ persen. Sehingga secara statistik Ho ditolak dan menerima H1. Maka model yang tepat untuk dipilih adalah model estimasi fixed effect.

Uji Hausman digunakan untuk memilih model yang terbaik antara fixed effect dan random effect. Tetapi pada saat pengujian Hausman output tidak dapat ditampilkan. Kemungkinan hal ini terjadi 
karena data yang sangat terbatas (data cross section hanya 2 (dua) jenis komoditas tuna-tuna big-eye dan tuna skipjack selama kurun waktu 11 tahun yaitu periode tahun 1999-2009).

Setelah Uji Hausman tidak dilakukan disimpulkan bahwa penelitian ini untuk (penawaran ekspor tuna nasional) dipergunaan model estimasi fixed effect dalam menganalisis independent variables antara dependent variable, yaitu jumlah armada penangkapan ikan dengan ukuran lebih dari 30 GT (KAPAL), Produk Nasional Bruto Indonesia (PDB), jumlah unit pengolahan ikan (UPITOT), dan jumlah produksi ikan tuna big-eye dan skypjack (PRODBS) dengan dependent variable penawaran ekspor tuna big-eye dan skypjack (PRODBS)

\subsubsection{Pengujian Hipotesis Untuk Data Panel}

Pengujian hipotesis data panel dilakukan menggunakan teknik regresi berganda dengan pendekatan model estimasi fixed effect. Hasil pengolahan data skunder dengan EViews pada Tabel 12 di bawah ini.

Hasil Uji Koefisien Determinasi $\left(\mathrm{R}^{2}\right)$ digunakan untuk menguji sebearapa besar pengaruh independent variable terhadap dependent variable-nya. Berdasarkan Tabel 12 di atas, diperoleh nilai adjusted $\mathrm{R}^{2}$ sebesar 0,95 yang berarti bahwa dependent variable penawaran ekspor tuna big-eye dan skypjack (OXBS) yang dijelaskan oleh independent variables armada penangkapan ikan dengan ukuran lebih dari 30 GT (KAPAL), Produk Nasional Bruto (PDB) Indonesia, jumlah unit pengolahan ikan (UPITOT), dan jumlah produksi ikan tuna big-eye dan skypjack (PRODAY) sebesar 95,0 persen. Hal ini berarti bahwa pengungkapan penawaran ekspor ikan tuna big-eye dan skypjack (OXBS) dipengaruhi oleh independent variables armada penangkapan ikan dengan ukuran lebih dari 30 GT (KAPAL), Produk Nasional Bruto (PDB) Indonesia, jumlah unit pengolahan ikan (UPITOT), dan jumlah produksi ikan tuna big-eye dan skypjack (PRODBS) sebesar 95,0 persen. Sisanya sekitar 5,0 persen dipengaruhi oleh variabel lain yang tidak diteliti dalam penelitian ini.

Uji $\mathrm{F}$ digunakan untuk melihat signifikansi secara simultan yaitu secara bersama-sama apakah variabel independents armada penangkapan ikan dengan ukuran lebih dari 30 GT (KAPAL), Produk Nasional Bruto (PDB) Indonesia, jumlah unit pengolahan ikan (UPITOT), dan jumlah produksi ikan tuna big-eye dan skypjack (PRODBS) berpengaruh signifikan ataukah tidak terhadap penawaran ekspor tuna big-eye dan skypjack (OXBS) pada tahun 1999-2009 pada tingkat signifikansi $\alpha=5$ persen.

Pada uji F (Uji Simultan), dapat dilihat pada Tabel 12 di berikut ini bahwa didapatkan $\mathrm{F}$ statistik 81,56 dengan nilai signifikansi probaabiitas $\mathrm{F}$ sebesar 0,0000 lebih kecil dari 0,05. Hal ini dapat dikatakan bahwa secara simultan terdapat pengaruh yang signifikan antara independent variables, seperti jumlah armada penangkapan ikan dengan ukuran lebih dari 30 GT (KAPAL), Produk Nasional Bruto Indonesia (PDB), jumlah unit pengolahan ikan (UPITOT), dan jumlah produksi ikan tuna big-eye dan skypjack (PROBS).berpengaruh signifikan terhadap penawaran ekspor tuna big-eye dan skypjack (PROBS) selama periode tahun 1999-2009 pada tingkat signifikansi $\alpha=5$ persen. 
Tabel 12. Hasil Regreasi Model Penawaran Ekspor Tuna Big-eye dan Skypjack

\begin{tabular}{|c|c|c|c|c|}
\hline Variable & Coefficient & Std. Error & t-Statistic & Prob. \\
\hline C & -767.2655 & 25859.14 & -0.029671 & 0.9767 \\
\hline KAPAL? & 0.995500 & 1.555959 & 0.639798 & 0.5314 \\
\hline PDB? & $-7.57 \mathrm{E}-10$ & 2.19E-07 & -0.003449 & 0.9973 \\
\hline PROD? & 0.138727 & 0.059991 & 2.312480 & 0.0344 \\
\hline UPITOT? & 274.5667 & 312.4088 & 0.878870 & 0.3925 \\
\hline \multicolumn{5}{|c|}{ Fixed Effects (Cross) } \\
\hline \multirow[t]{2}{*}{ _BIGEYE--C } & -3615.877 & & & \\
\hline & 3615.877 & & & \\
\hline \multicolumn{5}{|c|}{ Effects Specification } \\
\hline \multicolumn{5}{|c|}{ Cross-section fixed (dummy variables) } \\
\hline \multicolumn{5}{|c|}{ Weighted Statistics } \\
\hline R-squared & 0.962247 & \multirow{5}{*}{\multicolumn{2}{|c|}{$\begin{array}{l}\text { Mean dependent var } \\
\text { S.D. dependent var } \\
\text { Sum squared resid } \\
\text { Durbin-Watson stat }\end{array}$}} & 8.537439 \\
\hline Adjusted R-squared & 0.950449 & & & 5.155842 \\
\hline S.E. of regression & 1.161498 & & & 21.58523 \\
\hline F-statistic & 81.56180 & & & 1.891638 \\
\hline Prob(F-statistic) & 0.000000 & & & \\
\hline \multicolumn{5}{|c|}{ Unweighted Statistics } \\
\hline R-squared & 0.936401 & \multirow{2}{*}{\multicolumn{2}{|c|}{ Mean dependent var }} & 41340.33 \\
\hline Sum squared resid & $6.21 \mathrm{E}+08$ & & Durbin-Watson stat & 1.957767 \\
\hline
\end{tabular}

Pada Uji t statistik berikut ini dapat disampaikan sebagai berikut:

a. Pengaruh KAPAL Terhadap OXBS

Berdasarkan Tabel 14 di atas diperoleh signifikansi sebesar 0,53>0,05. Maka disimpulkan bahwa jumlah armada penangkapan ikan dengan ukuran lebih dari 30 GT (KAPAL) tidak berpengaruh secara signifikan terhadap penawaran ekspor tuna big-eye dan skypjack (OXBS).

Berdasarkan hasil estimasi menunjukkan bahwa armada penangkapan ikan dengan ukuran lebih dari 30 GT (KAPAL) berpengaruh positif terhadap penawaran ekspor tuna big-eye dan skypjack (OXBS). Hal ini menunjukkan bahwa semakin banyak menambah jumlah armada penangkapan ikan dengan ukuran lebih dari 30 GT (KAPAL) akan menyebabkan semakin meningkatnya jumlah penawaran ekspor tuna big-eye dan skypjack (OXBS) di pasar internasional. Nilai koefisien regresi armada penangkapan ikan dengan ukuran lebih dari 30 GT (KAPAL) sebesar 0,996 menunjukkan bahwa setiap peningkatan jumlah armada penangkapan ikan dengan ukuran lebih dari 30 GT (KAPAL) sebanyak 1 unit, maka jumlah penawaran ekspor tuna big-eye dan skypjack (OXBS) akan meningkat sekitar 0,996 ton.

b. Pengaruh PDB Indonesia Terhadap OXBS

Berdasarkan Tabel 12 di atas diperoleh signifikansi sebesar 0,997 >0,05. Maka disimpulkan bahwa Produk Domestik Bruto (PDB) Indonesia berpengaruh secara signifikan tidak berpengaruh terhadap penawaran ekspor tuna big-eye dan skypjack (OXBS).

Berdasarkan hasil estimasi menunjukkan bahwa Produk Domestik Bruto (PDB) Indonesia berpengaruh negatif terhadap penawaran ekspor penawaran ekspor tuna big-eye dan skypjack (OXBS). Hasil hipotesis ini tidak sesuai dengan teori (studi empiris) yang ada, yang berarti pengaruh Produk Domestik Bruto (PDB) Indonesia terhadap penawaran ekspor tuna big-eye dan 
skypjack (OXBS) yang positif tidak terbukti. Hal ini dimungkinkan terdapatnya faktor-faktor lain unik yang sudah di luar dari kebiasaan perilaku ekonomi pada umumnya.

\section{c. Pengaruh UPITOT Terhadap OXBS}

Berdasarkan Tabel 12 di atas diperoleh signifikansi sebesar 0,3925> 0,05 . Maka disimpulkan bahwa unit pengolahan ikan (UPITOT) tidak berpengaruh secara signifikan terhadap penawaran ekspor tuna Indonesia albacore dan yellowfin (OXA big-eye dan skypjack (OXBS).

Berdasarkan hasil estimasi menunjukkan bahwa unit pengolahan ikan (UPITOT) berpengaruh positif terhadap penawaran ekspor tuna big-eye dan skypjack (OXBS). Hal ini menunjukkan bahwa semakin meningkat jumlah unit pengolahan ikan (UPITOT) akan menyebabkan meningkatnya jumlah penawaran ekspor tuna big-eye dan skypjack (OXBS) di pasar internasional. Nilai koefisien regresi unit pengolahan ikan (UPITOT) sebesar 274,57 menunjukkan bahwa setiap peningkatan jumlah unit pengolahan ikan (UPITOT) sebesar 1 unit, maka jumlah penawaran ekspor tuna big-eye dan skypjack (OXBS) akan meningkat sekitar 274,57 ton.

d. Pengaruh PRODBS Terhadap OXBS

Berdasarkan Tabel 14 di atas diperoleh signifikansi sebesar 0,034 <0,05. Maka disimpulkan bahwa jumlah produksi ikan tuna big-eye dan skypjack (OXBS) berpengaruh secara signifikan terhadap jumlah penawaran ekspor tuna Indonesia big-eye dan skypjack (OXBS) .

Berdasarkan hasil estimasi menunjukkan bahwa produksi ikan tuna big-eye dan skypjack (OXBS) berpengaruh positif terhadap penawaran ekspor tuna big-eye dan skypjack (OXBS). Hal ini menunjukkan bahwa semakin meningkat produksi ikan tuna big-eye dan skypjack (OXBS) akan menyebabkan meningkatnya jumlah penawaran ekspor tuna big-eye dan skypjack (OXBS) di pasar internasional. Nilai koefisien regresi produksi ikan tuna big-eye dan skypjack (OXBS) sebesar 0,139 menunjukkan bahwa setiap peningkatan produksi ikan tuna big-eye dan skypjack (OXBS) sebesar 1 ton, maka jumlah penawaran ekspor tuna Indonesia big-eye dan skypjack (OXBS) akan meningkat sekitar 0,139 ton.

\section{KESIMPULAN DAN IMPLIKASI KEBIJAKAN}

\subsection{Kesimpulan}

Berdasarkan hasil perhitungan analisis MSCA dan regresi berganda terkait dengan ekspor tuna Indonesia di pasar internasional, dapat disimpulkan halhal sebagai berikut:

1. Selama periode 2000-2009, pertumbuhan ekspor ikan sebesar 5,2 persen banyak didukung oleh pertumbuhan ekspor tuna beku dan tuna olahan. Tuna skypjack menunjukkan pertumbuhan yang paling tinggi yaitu sekitar 19,8 persen. Tuna ness beku dan segar mengalami pertumbuhan yang lebih tinggi dibandingkan dengan rata-rata pertumbuhan dunia pada jenis komoditas tuna yang sama. Tuna beku yellowfin mempunyai pertumbuhan yang melebihi pertumbuhan dunia namun masih di bawah Philipina dan Thailand. Sementara itu, tuna olahan/pengawetan Indonesia masih tumbuh di bawah rata-rata pertumbuhan dunia dan 2 negara tetangga-Philipina dan Thailand.

2. Pertumbuhan berbagai komoditas tuna dari Indonesia tersebut nampaknya sejalan dengan pangsa pasar yang dialaminya. Pada umumnya komoditas tuna-tuna ness begar dan beku, tuna yellowfin beku, tuna skypjack beku, dan tuna skayjack olahan menunjukkan perubahan pangsa pasar yang semakin meningkat selama 2000-2009.

3. Sejalan dengan analisa CMSA dapat disampaikan bahwa perubahan ekspor komoditas perikanan tuna dintentukan 
oleh berbagai efek komponen yang mempengaruhi perubahan ekspor tuna itu sendiri. Efek pertumbuhan dunia untuk semua komoditas tuna Indonesia mempunyai pengaruh yang positif bagi pertumbuhan ekspor tuna masingmasing komoditas di ketiga negara tersebut. Seperti hasil-hasil sebelumnya, komoditas tuna nes segar dan beku, tuna yellowfin beku, tuna skypjacck olahan/ pengawetan menunjukan tingkat daya saing yang kuat di pasar dunia

4. Dari hasil regresi berganda terkait dengan penawaran ekspor tuna nasional dapat disimpulkan bahwa produk domestik bruto (PDB) mempunyai pengaruh yang kuat terhadap peningkatan penawaran ekspor tuna nasional. Hal ini mengindikasikan bahwa kemampuan Indonesia untuk meningkatkan produksi tuna untuk tujuan ekspor ke pasar internasional benar-benar terbukti.

5. Dari hasil regresi berganda terkait dengan penawaran ekspor tuna albacore dan yellowfin dapat disimpulkan bahwa PDB Indonesia mempunyai pengaruh yang signifikan terhadap penawaran ekspor tuna jenis komoditas albacore dan yellowfin di pasar internasional. Produk domestik bruto (PDB) Indonesia menunjukkan hubungan yang negatif terhadap penawaran ekspor tuna tersebut. Mengingat bahwa variabel PDB Indonesia ini signifikan terhadap perubahan penawaran ekspor tuna nasional, dalam hal ini bukan berarti bahwa kemampuan Indonesia cenderung menurun untuk meningkatkan produksi ikan tuna untuk tujuan ekspor di pasar internasional. Namun hal ini diduga terjadinya kecenderungan meningkatnya selera dan daya beli masyarakat Indonesia terhadap produk ikan tuna. Apabila pendapatan meningkat maka permintaan akan ikan tuna juga meningkat. Selain itu, hal ini juga dapat dibuktikan bahwa selama periode 2000-2009 rasio ekspor tuna Indonesia terhadap produksi tuna cenderung menurun dari 0,15 pada tahun 2000 menjadi 0,14 pada tahun 2009. Sementara itu, pertumbuhan produksi ikan tuna mencapai sekitar 4,4 persen yang relatif lebih tinggi dibanidngkan dengan pertumbuhan ekspor ikan tuna tersebut (3,8 persen). Dengan demikian, dapat diduga bahwa tidak semua hasil produksi ikan tuna tersebut diekspor dan bahkan diduga ada kecenderungan permintaan dan konsumsi ikan tuna di dalam negeri terus meningkat.

6. Dari hasil regresi berganda terkait dengan penawaran ekspor tuna big-eye dan sakyjack dapat disimpulkan bahwa produksi tuna big-eye dan skypjack mempunyai pengaruh yang signifikan terhadap penawaran ekspor tuna jenis komoditas big-eye dan skypjack di pasar internasional. Hal ini membuktikan bahwa penawaran ekspor tuna big-eye dan skypjack sangat tergantung oleh tingkat produksinya dari kedua jenis komoditas ikan tuna tersebut.

\subsection{Implikasi Kebijakan}

Sehubungan dengan hasil kesimpulan penelitian tersebut di atas, berikut ini dapat disampaikan hal-hal sebagai berikut:

1. Untuk mengantisipasi terhadap perkembangan atas penawaran ekspor tuna beku dan olahan/pengawetan di pasar internasional, perlu didukung dengan ketersediaan jumlah produksi yang memadai terutama untuk jenis tuna big-eye dan skypjack.

2. Diperlukan adanya pengembangan sarana dan prasarana perikanan yang memadai dalam rangka mengembangkan usaha di bidang industri tuna pengolahan/ pengawetan dan industri tuna beku. 
3. Perlu pembenahan terhadap pengelolaan dan peningkatan fungsi unit pengolahan ikan produk tuna sesuai dengan jenis komoditas ekspor tuna yang akan dikembangkan, seperti komoditas tuna yellowfin, albacore, big-eye, dan skypjack. Hal ini terutama terkait dengan ekspor tuna segar dan beku.

\section{DAFTAR PUSTAKA}

Afiff, Mohamed dan Chye, Tan E. 1992. ASEAN Pacific Trade Relation. ASEAN Economic Bulletin. March.

Alamsy, I.E. 2012. Ikan Tuna Indonesia Laris Manis, LSM Asing Berulah.

http:/republika.co.id/berita/nasi onal/umum/11/05/19/1lf3p7ika...[23 Januari 2012].

BAPPENAS 2006. Laporan Kajian Prospek Komoditas Unggulan Kelautan dan Perikanan.

Cahya, I.N. 2010. Analisis Daya Saing Ikan Tuna Indonesia di Pasar Internasional. Bogor: Departemen Agribisnis Fakultas Ekonomi dan Manajemen Institut Pertanian Bogor.

[DKP]. Departemen Kelautan dan Perikanan. 2005. Revitalisasi Perikanan. Jakarta: SBP

[DKP]. Departemen Kelautan dan Perikanan. 2007. Statistik Perikanan Tangkap Indonesia 2005. Jakarta.

[DKP]. Departemen Kelautan dan Perikanan. 2008. Statistik Ekspor Hasil Perikanan 2007. Direktorat Jenderal Perikanan Tangkap. Jakarta: Departemen kelautan dan Perikanan.

[Deperind]. Departemen Perindustrian. $2009 . \quad$ Roadmap Pengembangan Industri Pengolahan Hasil Laut. Jakarta:
Direktorat Jenderal Industri Agro dan Kimia.

FAO. 2000. FISHSTAT Plus: Universal Software for Fishery Statistical Time Series, Version 2.3. Fisheries Department, Fishery Information, Data and Statistics Unit. Available online at www.fao.org/fi/statist/FISOFT /FISHPLUS.asp

[FAO]. Food and Agriculture Organization. 2001. Multilateral Trade Negotiations on Agriculture: A Resource, Manual I, Module 1. Rome: Food and Agriculture Organization of the United Nations.

FAO. 2002. State of Fisheries and Aquaculture. Rome: Food and Agriculture Organization of the United Nations.

FAO. 2011. Food Outloook. Global Market Analysis. Edisi Juni 2011.

Firdaus, M. 2011. Aplikasi Ekonometrika Untuk Data Panel dan Time Series: Seri Metode Kuantitatif. Bogor: IPB Press.

FishStatJ (FAO 2011). www.fao.org

Gate, C.L., Phuong, L.Q, Maidir, I. 2007. International Trade Policy Analysis: A Handbook of Applied Metdholologies with Case Studies from Indonesia and East Asia. Jakarta: The European Union-Indonesia Trade Support Programme.

Geraci, V,J., and Prewo, W. 1977. Bilateral Trade Flow and Transport Cost. The Review of Economics and Statistics. February.

Gonarsyah, I. 2007. Tentang Pendefinisian Daya Saing Berbaisis Sumberdaya Alam. Bahan Ajar Perdagangan Internasional Lanjutan. Program Studi Ilmu Ekonomi Pertanian, Institut Pertanian Bogor, Bogor. 
Hill, C.W.L. (2005). International Business: Competing in the Global Marketplace. Fifth Edition. Boston: McGraw Hill Companies, Inc.

Jakaria. 2002. Kinerja Ekspor Manufaktur SITC 842 dan 843: Pendekatan CMS dan Model Graviti. Dalam Budi Santoso, Lukman Hakim, Sri Yani Kusumastuti. Kinerja Perdagangan Luar Negeri Indonesia Pada Masa Krisis: Suatu Kajian Empiris. Jakarta: Komite Penelitian Fakultas Ekonomi Universitas TRISAKTI.

Kijboonchoo, T. And Kalayanakupt, K. 2003. Comparative Advantage and Competitive Strenght of Thai Canned Tuna Export in the World Market: 1982-1998. ABAC Journal, 23, (1).

[KKP]. Kementerian Kelautan dan Perikanan. 2011. Kebijakan Importasi Ikan. Direktur Jenderal Pengolahan dan Pemasaran Hasil Perikanan (P2HP) Kementerian Kelautan dan Perikanan Republik Indonesia. Bahan disampaikan pada Rapat Dengar Pendapat Direktorat Jenderal (Ditjen) P2HP dengan Komisi IV DPRRI pada tanggal 25 Oktober 2011.

[KKP]. Kementerian Kelautan dan Perikanan (2011). Kebijakan Importasi Ikan. Direktur Jenderal Pengolahan dan Pemasaran Hasil Perikanan (P2HP) Kementerian Kelautan dan Perikanan Republik Indonesia. Bahan disampaikan pada Rapat Dengar Pendapat Ditjen P2HP dengan Komisi IV DPR-RI pada Taggal 25 Oktober 2011.

[KKP]. Kementerian Kelautan dan Perikanan. 2011. Kelautan dan
Perikanan Dalam Angka 2011. Jakarta.

Kent, G. 1983. The pattern of fish trade. ICLARM Newsletter 6(2): 1213.

Krugman, P.R., Obstfeld, M., Melitz, M.J. 2012. International Economics: Theory and Policy. Ninth Edition. Boston: AddisonWesley.

Kurien, J. 1998. Small-Scale Fisheries in the Context of Globalization, CDS Working Paper No. 289. Trivandrum, Kerala, India: Centre for Development Studies.

Lambaga, A. 2009. Akselerasi Ekspor Produk Perikanan Indonesia Melalui Penerapan Standar. Makassar: Prosiding PPI Standarisasi 2009.

Lindert P.H., Kindleberger C.P. 1995. Ekonomi Internasional. Edisi Kedelapan. Abdullah B, penerjemah. Jakarta: Erlangga. Terjemahan dari: International Economics $8^{\text {th }}$ edition.

Mensah, I. 2010. An Analysis of the Performance of Ghanaian Canned Export Tuna to EU Market (1999-2009). (Master's Degree Thesis in International Fisheries Management). UIT Norwegian College of Fisheries Science.

Nachrowi, N.D dan Usman H. 2006. Pendekatan Populer dan Praktis Ekonometrika Untuk Analisis Ekonomi dan Keuangan. Lembaga Penerbit Fakultas Ekonomi Universitas Indonesia. Jakarta.

Nazzaruddin. 1993. Komoditi Ekspor Pertanian: Perikanan dan Peternakan. Jakarta: Penebar Swadaya.

Poernomo, A. (2010). Pengolahan Hasil Perikanan: Membangun Citra, 
Menagguk Devisa. E-Notes BBRP2B. http://www.bbrp2b.kkp.go.id/ en/media-massa/pengolahanhasil-perikanan...[Diakses tanggal 5 Pebruari 2012].

Putthipokin, P. 2001. An Analysis of Comaparative Advantage of Thailand Canned Tuna Industry. (M.Sc Thesis). Kasetsart University.

Richardson, J.D. (1984). Constant Market Share Analysis of Export Growth. Journal of International Economics. Vol.1.

Salvatore, D. 1998. International Economics. Sixth Edition. New Jersey: Prentice-Hall, Inc.

Santoso, B. 2002. Kinerja Ekspor Non Migas Indonesia Ke Tiga Negara Eropa 1983-1995. Dalam Budi Santoso, Lukman Hakim, Sri Yani Kusumastuti. Kinerja Perdagangan Luar Negeri Indonesia Pada Masa Krisis: Suatu Kajian Empiris. Jakarta: Komite Penelitian Fakultas Ekonomi Universitas TRISAKTI.

Satria A., Anggraini, E., Solihin, A. 2009. Globalisasi Perikanan: Reposisi Indonesia? Bogor: IPB Press.

Sistem Informasi Agroindustri Berbasis Ekspor (SIABE), Bank
Indonesia. 2011. Diakses di http://www.bi.go.id/sipuk/id/?i $\mathrm{d}=3$

Tajerin dan Mursidin. 2006. Kendala Pengembangan Ekspor pada Industri Pengalengan Ikan di Indonesia di Kabupaten Banyuwangi, Propinsi Jawa Timur. Mangrove dan Pesisir. Vol.VI No.2. Jakarta. Halaman 23-44.

Tajerin et.al. 2009. Ekonomi Udang: Model, Analisis, dan Simulasi Kebijakan. Balai Besar Riset Sosial Ekonomi Kelautan dan Perikanan. Badan Riset Kelautan dan Perikanan. Departemen Kelautan dan Perikanan. Jakarta.

Tambunan, Tulus. 2000. Perdagangan Internasional dan Neraca Pembayaran: Teori dan Temuan Empiris. Jakarta: Penerbit Pustaka LP3ES.

[UNComtrade]. United Nations Commodity Trade Statistics Database. 2011. http://unstats.un.org/unsd/trade /imts/anntotpubs.htm. [Diakses tanggal 14 Desember 2011].

Verbeek, M. 2004. A Guide to Modern Econometrics. Second Edition. Rotterdam: John Wiley \& Sons, Ltd. 